\title{
THE EFFECT OF REHABILITATION ON HEART RATE VARIABILITY IN PATIENTS WITH PARKINSON'S DISEASE
}

\author{
Petr Uhlír, Jaroslav Opavský, Amr Mohamed Zaki Zaatar
}

Faculty of Physical Culture, Palacký University, Olomouc, Czech Republic

Submitted in August, 2012

BACKROUND: Parkinson's disease includes disorders of the motor and autonomic functions (Oka et al., 2006). It is necessary to influence both systems to improve the health state of the patients. The effects of rehabilitation on the autonomic nervous system (ANS) are not clear yet.

OBJECTIVE: The aim of this study was to evaluate differences in the autonomic nervous system (ANS) regulation following a rehabilitation programme in patients with Parkinson's disease (PD) with the use of spectral analysis of heart rate variability (SAHRV) in a supine-standing-supine test. We wanted to compare findings in patients with PD prior to a rehabilitation programme with age-matched healthy controls.

METHODS: The group under study involved ten subjects (mean age $69.2 \pm 5.9$ years) with Parkinson's disease $(9.2 \pm 3.0$ points according to the Webster scale), with a disease duration mean $3.3 \pm 1.2$ years. All patients used L-Dopa. We used the VarCor PF7 diagnostic system for the assesment of SAHRV. The findings in patients with PD before the rehabilitation programme were compared with those in a group of age-matched healthy subjects in a control group ( $n=40$; mean age $64.0 \pm 7.4$ years).

RESULTS: Significantly lower values of the LF (low frequency) and HF (high frequency) components were found in patients with PD in a repeated supine position, in comparison with those in a group of control subjects. The value of Total power in the same position was significantly lower in the group of patients with PD, too. Spectral parameter Power HF increased significantly and the Ratio LF/HF decreased significantly in patients with PD after rehabilitation programme.

CONCLUSIONS: A decrease of the activity of the autonomic nervous system, which evidences disturbances of cardiovascular regulation, was found with the use of SAHRV in patients with PD. The value of the spectral parameter Power HF was significantly higher and the Ratio LF/HF was significantly lower in patients with PD after rehabilitation programme in comparison with their initial values. It could reflect positive changes in autonomic regulation in these patients.

Keywords: Parkinson's disease, spectral analysis, heart rate variability, autonomic nervous system.

\section{INTRODUCTION}

Parkinson's disease includes disorders of the motor and autonomic functions (Oka et al., 2006). It is necessary to influence both systems to improve the health state of the patients.

Motor disturbances are improved by a series of methods, used in medical rehabilitation, while influencing of ANS during and after medical rehabilitation was registered later, due to metodological difficulties. Several studies confirmed a disturbance of the sympatho-vagal balance in PD patients (Devos et al., 2003; Gurevich et al., 2004).

Autonomic disturbances in PD patients are characterized by seborrhoea (facies oleosa), urinary incontinence, nocturia, gastric dysmotility, altered sexual function, thermoregulatory disturbances, orthostatic hypotension (Oka et al., 2007) and changes of heart rate variability. The purpose of this study was to diagnose the effect of rehabilitation programme, performed at the faculty Department of Physiotherapy, on parameters of ANS function (Opavský et al., 1998; Opavský, 2002). We used SAHRV in order to evaluate sympatho-vagal balance. Three main spectral components - VLF (very low frequency), LF (low frequency), HF (high frequency) and its parameters are distinguished in a heart rate spectrum calculated from short-term recordings. We used orthoclinostatic stimulation in a supine-standing-supine test (Opavský et al., 1994).

Results of the study should contribute to the assessment of the effect of rehabilitation programme on SAHRV parameters in patients with PD.

\section{MATERIAL AND METHODS}

The group under study involved ten subjects (mean age $69.2 \pm 5.9$ years) with Parkinson's disease (dis- 
ease severity $9.2 \pm 3.0$ points according to the Webster Scale - between mild and moderate disability) (Webster, 1968), with a disease duration mean $3.3 \pm 1.18$ years. All patients used L-Dopa. We used the VarCor PF7 diagnostic system utilising ,short term“ SAHRV. SAHRV was used as a sensitive, non invasive method for the evaluation of the cardiac autonomic nervous system activity. The frequency spectrum is divided in the course of the short term registrations into three major components:

1. VLF component (very low frequency, from 20 to $50 \mathrm{mHz}$ ), its origin has not been fully explained, yet.

2. LF component (low frequency, from 50 to $150 \mathrm{mHz}$, mainly about $100 \mathrm{mHz}$ ) component is explained mostly as a reflection of arterial baroreceptor sympathetic activity (Pagani et al., 1992).

3. HF component (high frequency from 150 to $400 \mathrm{mHz}$ ) component represents a vagal activity a associated with breathing (Malik \& Camm, 1990).

The ECG signal is obtained with the help of an electrode belt POLAR or electrodes placed on the thorax. A transmitter of this system works at a frequency of $433 \mathrm{MHz}$ (Štěpaník et al., 2005). The ECG signal was processed in $\mathrm{PC}$ with the use of special software for this diagnostic system (Salinger et al., 2005).

This process was performed between 8.00 and 11.00 a.m. in a supine-standing-supine orthoclinostatic test before and after rehabilitation programme. Each interval of the orthoclinostatic test lasted at least 300 heart beats or 300 seconds. The SAHRV parameters used - Power LF, Power HF, Power VLF [ $\mathrm{ms}^{2}$ ], and Total power $(\mathrm{VLF}+\mathrm{LF}+\mathrm{HF})\left[\mathrm{ms}^{2}\right]$, and Ratio $\mathrm{LF} / \mathrm{HF}$. The findings from the repeated supine position in this test have been presented and statistically evaluated. Findings in patients with PD before the rehabilitation programme were compared by using the Mann-Whitney test with those in a group of age-matched healthy subjects in a control group $(n=40$; mean age $64.0 \pm 7.4$ years $)$. Findings in a group of patients with PD before and after rehabilitation programme were compared by means of the Wilcoxon test. Rehabilitation procedures were conducted by an experienced physiotherapist for the whole group of patients. Rehabilitation procedures were focused on exercises with active and passive movements, breathing exercises, gait re-education, exercise with devices, and relaxation procedures (Šlachtová \& Dupalová, 2010). These were performed twice a week for a period of six weeks. On other days, patients practiced and mastered exercises at home. Each rehabilitation session lasted one hour and included three phases: initial part, main part and final part. The initial part of the rehabilitation session lasted 10 minutes. The main part was divided into the fitness phase (20 minutes) and the treatment phase ( 25 minutes). The final (calming) phase lasted 5 minutes.

\section{RESULTS}

Significantly lower values of the LF (low frequency) and HF (high frequency) components were found in patients with Parkinson's disease in a repeated supine position of the supine-standing-supine test in comparison with control subjects (TABLE 1). The value of Total power in the same position was significantly lower in a group of patients with PD (TABLE 1). The Ratio LF/ HF was significantly higher in a group of PD patients in a repeated supine position in the test used (TABLE 2).

Spectral parameter Power HF significantly increased (TABLE 3) and Ratio LF/HF significantly decreased (TABLE 4) in patients with PD after rehabilitation programme.

\section{TABLE 1}

Values of the spectral parameters Power VLF, Power LF, Power HF and Total power between patients with PD before rehabilitation programme and the control group in a repeated supine position of the supine-standing-supine test

\begin{tabular}{|l|l|c|c|c|}
\hline Parameter & & Patients & Control & p \\
\hline Power VLF & mean & 109.15 & 167.70 & 0.52 \\
\hline & SD & 92.36 & 198.16 & \\
\hline Power LF & mean & 100.08 & 255.47 & 0.03 \\
\hline & SD & 77.47 & 263.52 & \\
\hline Power HF & mean & 111.71 & 432.12 & 0.0002 \\
\hline & SD & 111.74 & 307.5 & \\
\hline Total power & mean & 320.94 & 855.29 & 0.0004 \\
\hline & SD & 216.73 & 567.15 & \\
\hline
\end{tabular}

Legend: Power VLF - spectral power of the very low frequency component (VLF), Power LF - spectral power of the low frequency component (LF), Power HF - spectral power of the high frequency component (HF), Total power - sum of the spectral powers of the VLF (very low frequency) + LF (low frequency) + HF (high frequency) components, Control - control group, Patients - group of patients with PD, $\mathrm{p}$ - significance level

\section{TABLE 2}

Values of the Ratio LF/HF between patients with PD before rehabilitation programme and the control group in a repeated supine position of the supine-standingsupine test

\begin{tabular}{|l|l|c|c|c|}
\hline Parameter & & Patients & Control & p \\
\hline Ratio LF/HF & mean & 1.65 & 0.98 & 0.03 \\
\hline & SD & 1.39 & 1.87 & \\
\hline
\end{tabular}

Legend: LF - low frequency component, HF - high frequency component, Patients - group of patients with PD, Control - control group, $\mathrm{p}$ - significance level 


\section{TABLE 3}

Values of the spectral parameters Power VLF, Power LF, Power HF and Total power between patients with PD before and after rehabilitation programme in a repeated supine position of the supine-standing-supine test

\begin{tabular}{|l|l|r|r|c|}
\hline Parameter & & Before & After & p \\
\hline Power VLF & mean & 109.15 & 142.78 & 0.76 \\
\hline & SD & 92.36 & 185.79 & \\
\hline Power LF & mean & 100.08 & 94.89 & 0.14 \\
\hline & SD & 77.47 & 129.17 & \\
\hline Power HF & mean & 111.71 & 187.18 & 0.005 \\
\hline & SD & 111.74 & 183.14 & \\
\hline Total power & mean & 320.94 & 424.86 & 0.72 \\
\hline & SD & 216.73 & 310.72 & \\
\hline
\end{tabular}

Legend: Power VLF - spectral power of the very low frequency component, Power LF - spectral power of the low frequency component, Power HF - spectral power of the high frequency component, Total power - sum of the spectral powers of the VLF (very low frequency) + LF (low frequency) + HF (high frequency) components, Before - group of patients with PD before rehabilitation programme, After - group of patients with PD after rehabilitation programme, $\mathrm{p}$ - significance level

\section{TABLE 4}

Values of the Ratio LF/HF between patients with PD before and after rehabilitation programme in a repeated supine position of the supine-standing-supine test

\begin{tabular}{|l|l|c|c|c|}
\hline Parameter & & Before & After & p \\
\hline Ratio LF/HF & mean & 1.65 & 0.72 & 0.04 \\
\hline & SD & 1.39 & 0.7 & \\
\hline
\end{tabular}

Legend: LF - low frequency component, HF - high frequency component, Before - group of patients with PD before rehabilitation programme, After - group of patients with PD after rehabilitation programme, $\mathrm{p}$ - significance level

\section{DISCUSSION}

Spectral analysis of heart rate variability is a technique that measures the beat to beat variability in R-R intervals, which reflects changes in autonomic reactivity and their impact on cardiovascular function.

Heart rate variability has been investigated during postural stress as a means of identifying changes within the frequency spectra corresponding to a sympathetic stimulus and vagal withdrawal (Vybiral et al., 1989; Hynynen et al., 2011; Chenier-Hogan et al., 2012).

In the able-bodied population, increase in the low frequency component of heart rate variability was reported during postural stress and was associated with significant reductions in the high frequency component, suggesting augmented sympathetic and diminished vagal cardiac control. Parameter Power HF represents mainly parasympathetic-vagal-activity (Montano et al., 1994; Dantas et al., 2010; Palova et al., 2012).

The clinical manifestations of Parkinson's disease are not restricted to the classic triad of akinesia, rigidity and tremor but also include autonomic nervous system disorders such as sialorrhea, seborrhoea, hyperhidrosis, constipation, sphincter disturbances, dysphagia, postural hypotension and other vasomotor abnormalities, heat intolerance and impotence. Cardiovascular autonomic functions are markedly disturbed in patients with Parkinson's disease. It can lead, as one of the important factors, to an increase in mortality in these patients (Kallio et al., 2002).

Results of this study correspond to the results of the study done by Rodriguez et al. (1996), where in patients with PD a decrease of spectral power in high and low spectral components in supine position was registered.

Similarly, there were decreases in all evaluated spectral components in patients with the PD in studies performed by Pursiainen et al. (2002) and Haapaniemi et al. (2001).

Heart rate variability differences between patients with PD and age matched healthy controls were registered in frequency domain in the study of Kallio et al. (2002).

Comparison between the state before and after rehabilitation programme lasting for six weeks showed the significant increase in the parameter Power HF and significant decrease in the Ratio LF/HF. Furthermore, tendency towards an increase in the parameter Total power and decrease in the parameter Power LF in repeated sitting position of the supine-standing-supine test in patients with PD, were registered too.

Presented data support the hypothesis that both sympathetic a parasympathetic control of heart activity are impaired in Parkinson's disease (Shibata et al., 2009; Probst et al., 2008) and this dysfunction can be assessed by frequency-domain analysis of heart rate changes.

Rehabilitation programme led to an increase in $\mathrm{HF}$ component of the SAHRV, which has been considered as manifestation of the cardiac vagal activity.

\section{CONCLUSION}

1. A decrease in the activity of the cardiac autonomic nervous system, which evidences disturbances of cardiovascular regulation, was found, with the use of SAHRV, in patients with Parkinson's disease.

2. Spectral parameter Power HF increased significantly and the Ratio LF/HF decreased significantly in patients with Parkinson's disease after rehabilitation programme. It could reflect positive changes in autonomic regulation in these patients after rehabilitation. 


\section{ACKNOWLEDGEMENT}

The study has been supported by the research grant from the Ministry of Education, Youth and Sports of the Czech Republic (No. MSM 6198959221) "Physical Activity and Inactivity of the Inhabitants of the Czech Republic in the Context of Behavioral Changes”.

\section{REFERENCES}

Dantas, E. M., Gonçalves, C. P., Silva, A. B. T., Rodrigues, S. L., Ramos, M. S., Andreão, R. V., Pigmentel, E. B., Lunz, W., \& Mill J. G. (2010). Reproducibility of heart rate variability parameters measured in healthy subjects at rest and after a postural change maneuver. Braz. J. Med. Biol. Res., 43(10), 982-988.

Devos, D., Kroumova, M., Bordet, R., Vodougnon, H., Guieu, J. D., Libersa, C., \& Destee, A. (2003). Heart rate variability and Parkinson's disease severity. J. Neural. Transm., 110(9), 997-1011.

Gurevich, T. Y., Groozman, G. B., Giladi, N., Drory, V. E., Hausdorff, J. M., \& Korczyn A. D. (2004). R-R interval variation in Parkinson's disease and multiple system atrophy. Acta Neurologica Scandinavia, 109, 276-279.

Haapaniemi, T. H., Pursiainen, V., Korpelainen, J. T., Huikuri, H. V., Sotaniemi, K. A., \& Myllylä, V. V. (2001). Ambulatory ECG and analysis of heart rate variability in Parkinson's disease. J. Neurol. Neurosurg. Psychiatry, 70(3), 305-310.

Hynynen, E., Konttinen, N., Kinnunen, U., Kyröläinen, H., \& Rusko, H. (2011). The incidence of stress symptoms and heart rate variability during sleep and orthostatic test. Eur. J. Appl. Physiol., 111(5), 733-741.

Chenier-Hogan, N., Brown, C. A., Hains, S. M., \& Parlow J. L. (2012). Heart rate variability response to standing in men and women receiving d, 1-sotalol following coronary artery bypass graft surgery. Biol. Res. Nurs., 14(1), 38-47.

Kallio, M., Suominen, K., Bianchi, A. M., Mäkikallio, T., Haapaniemi, T., Astafiev, S., Sotaniemi, K. A., Myllyä, V. V., \& Tolonen, U. (2002). Comparsion of heart rate variability analysis methods in patients with Parkinson's disease. Med. Biol. Eng. Comput., 40(4), 408-414.

Malik, M., \& Camm, A. J. (1990). Significiance of long term components of heart rate for the further prognosis after acute myocardial infarction. Cardiovascular Research, 24, 793-803.

Montano, N., Ruscone, T. G., Porta, A., Lombardi, F., Pagani, M., \& Malliani, A. (1994). Power spectrum analysis of heart rate variability to assess the changes in sympathovagal balance during graded orthostatic tilt. Circulation 90(4), 1826-1831.

Oka, H., Mochio, S., Onouchi, K., Merita, M., Yoshioka, M., \& Inoue, K. (2006). Cardiovascular dysautonomia in de novo Parkinson's disease. J. Neurol. Sci., 241(1-2), 59-65.

Oka, H., Yoshika M., Onouchi, K., Morita, M., Mochio, S., Suzuki, M., Hirai, T., Ito, Y., \& Inoue, K. (2007). Characteristics of orthostatic hypotension in Parkinson's disease. Brain, 130(9), 2425-2432.

Opavský, J. (2002). Autonomní nervový systém a diabetická autonomní neuropatie: Klinické aspekty a diagnostika. Praha: Galén.

Opavský J., Pumprla J., Salinger J., Howorka K., Thoma H., \& Vychodil R. (1994). Spektrální analýza variability srdeční frekvence - př́nos pro diagnostiku diabetické autonomní neuropatie. Scripta Medica (Fac. Med. Univ. Brunensis Masarykianae), 67, 29-32.

Opavský, J., Salinger, J., Velísková, J., Rodová, D., Urbánek, K., \& Opavská, H. (1998). Spektrální analýza variability srdeční frekvence $v$ hodnocení funkce autonomního nervového systému u Parkinsonovy nemoci. Česká a slovenská neurologie a neurochirurgie, 61(94), 28.

Pagani, M., Rimoldi, O., \& Malliani, A. (1992). Low frequency components of cardiovascular variabilities as markers of sympathetic modulation. Trends in pharmacological science 13(2), 50-54.

Palova, S., Havlin, J., \& Charvat J. (2012). The association of heart rate variability examined in supine and standing position with ambulatory blood pressure monitoring in anorexia nervosa. Neuro. Endocrinol. Lett., 33(2), 196-200.

Probst, A., Bloch, A., \& Tolnay, M. (2008). New insights into the pathology of Parkinson's disease: Does the peripheral autonomic system become central? European Journal of Neurology, 15, 1-4.

Pursiainen, V., Haapaniemi, T. H., Korpelainen, J. T., Huikuri, H. V., Sotaniemi, K. A., \& Myllylä, V. (2002). Circadian heart rate variability in Parkinson's disease. J. Neurol., 249(11), 1535-1540.

Rodriguez, M., Sabate, M., \& Troncoso, E. (1996). Time and frequency domain analysis for the assessment of heart autonomic control in Parkinson's disease. J. Neural. Transm., 103(4), 447-454.

Salinger, J., Štěpaník, P., Kolisko, P., Stejskal, P., Theuerová, Š., Elfmark, M., Gwozdziewiczová, S., \& Krejčí, J. (2005). Measurement of breathing frequency from ECG in the examination of autonomous nervous system activities: Suggested methods and their verification. Acta Universitatis Palackianae Olomoucensis. Gymnica, 35, 95-103.

Shibata, M., Morita, Y., Shimizu, T., Takahashi, K., \& Suzuki, N. (2009). Cardiac parasympathetic dysfunction concurrent with cardiac sympathetic dener- 
vation in Parkinson's disease. Journal of Neurological Sciences, 276, 79-83.

Šlachtová, M., \& Dupalová, D. (2010). Kinezioterapie u Parkinsoniků. In D. Smékal \& J. Urban (Eds.), Sborník abstraktů III. absolventské konference Katedry fyzioterapie Fakulty tělesné kultury UP (pp. 12-13). Olomouc: F. G. P. studio.

Štěpaník, P., Salinger, J., Novotný, J., Stejskal, P., \& Krejčí, J. (2005). Diagnostic system, type VarCor PF7, for non invasive assessment of the function of the autonomic nervous system [CD-ROM]. In F. Vaverka (Ed.), Movement and Health $-4^{\text {th }}$ International Conference - Proceedings. Olomouc: Univezita Palackého.

Vybiral, T., Bryg, R. J., Maddens, M. E., \& Boden, W. E. (1989). Effects of passive tilt on sympathetic and parasympathetic components of heart rate variability in normal subjects. Am. J. Cardiol., 63, 1117-1120.

Webster, D. D. (1968). Critical analysis of the disability in Parkinson's disease. Modern Treatment, 5(2), 257-282.

\section{EFEKT REHABILITACE NA VARIABILITU SRDEČNÍ FREKVENCE} U PACIENTŮ S PARKINSONOVOU NEMOCÍ (Souhrn anglického textu)

VÝCHODISKA: Parkinsonova nemoc zahrnuje jak poruchy motorických, tak autonomních funkcí (Oka et al., 2006). Ke zlepšení celkového stavu organismu pacienta je proto třeba ovlivnit oba tyto systémy. Efekt rehabilitace na autonomní nervový systém (ANS) není dosud zcela objasněn.

CÍLE: Cílem studie bylo hodnotit vliv rehabilitace pomocí metody spektrální analýzy variability srdeční frekvence (SAVSF) u pacientů s Parkinsonovou nemocí (PN) a dále porovnat výchozí nálezy těchto pacientů s kontrolní skupinou.

METODIKA: Studie se účastnilo deset pacientů (průměrný věk $69,2 \pm 5,9$ let $) \mathrm{s} P N(9,2 \pm 3,0$ bodů dle Websterovy škály, tj. na hranici lehkého a středně těžkého postižení). Délka onemocnění byla $\mathrm{v}$ rozmezí $3,3 \pm 1,2$ let. Všichni pacienti uživali preparát L-DOPA. K hodnocení SAVSF v ortoklinostatické zkoušce lehstoj-leh byl použit diagnostický systém VarCor PF7. Nálezy pacientů před rehabilitací byly porovnány s kontrolní skupinou ( $\mathrm{n}=40$, průměrný věk $64,0 \pm 7,4$ let).

VÝSLEDKY: Signifikantně nižší hodnoty spektrálního výkonu nízkofrekvenční komponenty (LF) a vysokofrekvenční komponenty (HF) byly zjištěny u pacientů s PN v opakovaném lehu ortoklinostatické zkoušky lehstoj-leh. Hodnota celkového spektrálního výkonu (Total power) ve stejné pozici byla signifikantně nižší u skupiny pacientů s PN, při porovnání s nálezy u kontrolní skupi- ny. Spektrální parametr Power HF se signifikantně zvýšil a Poměr LF/HF signifikantně snížil u pacientů s PN po rehabilitaci, při porovnání s výchozími hodnotami.

ZÁVĚRY: Pomocí metody SAVSF byl zjištěn pokles kardiální autonomní regulační aktivity u pacientů s PN. Tento nález svědčí pro poruchu kardiovaskulární autonomní regulace u těchto pacientů. U pacientů po rehabilitaci bylo zjištěno signifikantní zvýšení hodnoty spektrálního výkonu komponenty HF (Power HF) a signifikantní snížení poměru výkonů nízkofrekvenční a vysokofrekvenční komponenty (Poměr LF/HF), ve srovnání se vstupními hodnotami. Tyto nálezy mohou odrážet pozitivní změny $\mathrm{v}$ autonomní regulaci těchto pacientů.

Klíčová slova: Parkinsonova nemoc, spektrální analýza, variabilita srdeční frekvence, autonomní nervový systém.

\section{PhDr. Petr Uhlír}

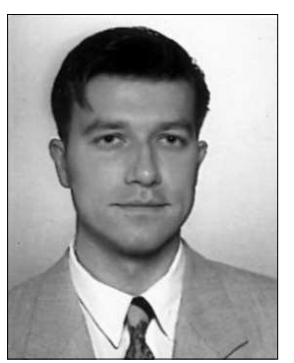

Palacký University, Olomouc

Faculty of Physical Culture

tř. Míru 115

77111 Olomouc

Czech Republic

\section{Education and previous work experience}

2000 - Faculty of Physical Culture, Palacký University, Olomouc, Department of Physiotherapy - Master Degree in Physiotherapy.

2000-2005 - Faculty of Physical Culture, Palacký University, Olomouc, Department of Physiotherapy - Assistant.

Since 2005 - Faculty of Physical Culture, Palacký University, Olomouc, Department of Physiotherapy - Assistant Professor.

\section{Scientific orientation}

Physiotheray, rehabilitation, heart rate variability.

\section{First-line publication:}

Uhliŕ, P., \& Opavský, J. (2006). Vliv reflexní masáže na autonomní regulaci variability srdeční frekvence. In D. Smékal \& J. Urban (Eds.), Sborník abstraktů I. absolventské konference Katedry fyzioterapie Fakulty tělesné kultury UP (pp. 55-58). Olomouc: Univerzita Palackého.

Uhlír, P. (2008). Pohybová cvičení seniorů. Olomouc: Univerzita Palackého.

Uhliř, P. (2008). Kinezioterapie u klientů vyššího věku. In H. Bednářová (Ed.), Sborník př́spěvků - Aktivní v každém věku II (pp. 9-11). Olomouc: Univerzita Palackého. 
Uhlír, P. (2009). Pohybové prostř̌edky cvičební jednotky pro seniory. In H. Bednářová (Ed.), Sborník př́spěvků - Aktivní v každém věku III (pp. 11-12). Olomouc: Univerzita Palackého.

Uhlír, P., Opavský, J., Zaatar, A., \& Betlachová, M. (2010). Spectral analysis of heat rate variability in patients with spinal cord injury. Acta Universitatis Palackianae Olomucensis. Gymnica, 40(2), 55-62.
Uhlír, P., Opavský, J., Zaatar, A., Betlachová, M., Knap, J., \& Klapalová, A. (2010). Autonomní reaktivita u osob s postižením lokomoce po poranění míchy. Česká kinantropologie, 14(4), 72-81.

Uhliŕ, P., Betlachová, M., \& Kuchařová, Z. (2011). Bolesti dolní části zad u zdravotních sester a jejich prevence. Medicína pro praxi, 8(10), 438-440. 